\title{
Comparative studies on the removal of copper (II) by Ulva fasciata activated carbon and commercially activated carbon
}

\author{
Suresh Jeyakumar R.P. ${ }^{1}$, Chandrasekaran V. $^{2^{*}}$ \\ ${ }^{1}$ Vivekananda College of Arts and Sciences for Women (Autonomous), Department of chemistry, Tiruchengode-637205, India \\ ${ }^{2}$ Govt. Arts College, Department of chemistry, Karur-639005, India \\ * Corresponding author: e-mail: chandru-v-m@yahoo.com.in
}

In this work, the efficiency of Ulva fasciata sp. activated carbons (CCUC, SCUC and SSUC) and commercially activated carbon (CAC) were studied for the removal of $\mathrm{Cu}$ (II) ions from synthetic wastewater. Batch adsorption experiments were carried out as a function of $\mathrm{pH}$, contact time, initial copper concentration and adsorbent dose. The percentage adsorption of copper by CCUC, SSUC, SCUC and CAC are $88.47 \%, 97.53 \%, 95.78 \%$ and $77.42 \%$ respectively. Adsorption data were fitted with the Langmuir, Freundlich and Temkin models. Two kinetic models pseudo first order and the pseudo second order were selected to interpret the adsorption data.

Keywords: Ulva fasciata sp., synthetic wastewater, Activated carbons, Adsorption, Langmuir

\section{INTRODUCTION}

Water pollution is one of the most debatable as almost all inorganic or organic wastes are discharged through the aquatic route either in water soluble or insoluble forms ${ }^{1}$. Among the wastes, mobile and soluble heavy metal species are not biodegradable and tend to accumulate in living organisms, causing various diseases and disorders. Heavy metal contamination exists in aqueous waste streams of many industries such as metal plating facilities, mining operations, and tanneries ${ }^{2}$. Copper, which is one of the most important heavy metals used in electroplating industries and it causes serious toxicological effects at high doses, after uptake it is known to deposit in brain, skin, liver, pancreas and myocardium ${ }^{3}$. For these reasons EPA (U.S.A) has regulated drinking water concentrations not to exceed $1.3 \mathrm{ppm}$ for copper ${ }^{4}$.

The removal and recovery of heavy metals from wastewater is important for environmental protection and human health. Several methods have been used to remove heavy metals in high concentrations from aqueous solutions, including precipitation, ion exchange, evaporation, electroplating, and membrane processes. These methods are, however, either inefficient or expensive when heavy metals are present at low concentrations ${ }^{5}$. It is therefore, necessary to find new technologies or materials for removing heavy metal ions from wastewater. Adsorption of heavy metals is one of the possible alternative technologies involved in the removal of toxic metals from industrial waste streams and natural waters using low-cost adsorbents. It is a potential and interesting alternative to conventional processes for the removal of metals, such as ion exchange processes ${ }^{6,7}$. It is a rapid, reversible, economical and ecofriendly technology in contrast to conventional chemical methods of removing metal ions from the industrial effluents. Adsorption of metal ions from the aquatic system using microbial biomass, including algae, fungi and bacteria has gained importance in recent years ${ }^{\mathbf{8 , 9}}$. Among the biological materials marine algae otherwise known as seaweeds have been reported to have high metal binding capacities due to the presence of polysaccharides, proteins or lipid on the cell wall surface containing functional groups such as amino, hydroxyl, carboxyl and sulphate, which can act as binding sites for metals ${ }^{10-12}$.

Activated carbon has undoubtedly been the most popular and widely used as adsorbent in wastewater treatment applications throughout the world. However, activated carbon remains an expensive material since the higher the quality of activated carbon, the greater its $\operatorname{cost}^{13}$. Therefore, searching for a low cost activated carbon and other adsorbent materials are of great importance for the wastewater treatment ${ }^{14-16}$. Ulva fasciata $\mathrm{sp}$. algal cell walls are porous and allow the free passage of molecules and ions in aqueous solutions. The constituents of the cell wall provide an array of ligands with different functional groups capable of binding various heavy metals ${ }^{\mathbf{1 7}}$.

Hence, the present investigation aimed to remove copper from its aqueous solution using activated carbons prepared from a marine green algae Ulva fasciata sp. and commercially activated carbon as adsorbent materials for various parameters like $\mathrm{pH}$ of the solution, contact time, initial $\mathrm{Cu}$ (II) concentration and adsorbent concentration. The adsorption capacity of this adsorption process was estimated using Langmuir, Freundlich and Temkin isotherms. The kinetics of the adsorption process was investigated using Lagergren equations.

\section{MATERIALS AND METHODS}

\section{Preparation of Activated Carbon Adsorbent}

The green marine algae Ulva fasciata sp. in the present study were collected from the coastal area of Kanyakumari district, Tamil Nadu, India. The collected algae were washed with tap water and further by deionized water several times to remove impurities. The washing process was continued till the removal of all dirt. The washed algae were then completely dried in the sun light for seven days. Then the dried algae Ulva fasciata were pretreated with Calcium Chloride, Sodium Sulphate and Sodium Cabonate salts respectively. It is further carbonized as three types, known as Calcium Chloride treated Ulva fasciata Carbon (CCUC), Sodium Sulphate Treated Ulva fasciata Carbon (SSUC) and Sodium Carbonate treated Ulva fasciata Carbon (SCUC). 


\section{Calcium Chloride Treated Ulva fasciata Carbon (CCUC)}

The dried algae Ulva fasciata to be carbonized is impregnated with the solution of chloride salts such as calcium chloride for 24 hours. Accordingly sufficient quantities were soaked well with $10 \%$ chloride solution of 5 liters capacity respectively so that the solution get well adsorbed for a period of 24 hours. At the end of 24 hours the excess solution were decanted off and air dried. Then the materials were placed in muffle furnace carbonized at $400^{\circ} \mathrm{C}$. The dried materials were powdered and activated in a muffle furnace kept at $800^{\circ} \mathrm{C}$ for a period of 10 minutes. After activation, the carbon was washed sufficiently with $4 \mathrm{~N} \mathrm{HCl}$ to remove the cations. Then the materials were washed with plenty of water to remove excess acid, dried and powdered.

\section{Sodium Sulphate Treated Ulva fasciata Carbon (SSUC)}

In this method the dried algae Ulva fasciata to be carbonized were soaked in $10 \%$ solutions of sodium sulphate for a period of 24 hours. After impregnation, the liquid portion was decanted off and then dried. The dried mass was subjected to carbonization process at $400^{\circ} \mathrm{C}$ powdered well and finally thermally activated at $800^{\circ} \mathrm{C}$ for 10 minutes ${ }^{18}$.

\section{Sodium Carbonate Treated Ulva fasciata Carbon (SCUC)}

In this method the dried algae Ulva fasciata to be carbonized were soaked with $10 \%$ sodium carbonate solution for a period of 24 hours. After impregnation, the liquid portion was decanted off and the material dried. The dried mass was subjected to carbonization process at $400^{\circ} \mathrm{C}$ powdered well and finally thermally activated at $800^{\circ} \mathrm{C}$ for a period of 10 minutes.

In the present study the powdered activated carbons (CCUC, SSUC and SCUC) of algae Ulva fasciata in the range of $150 \mu \mathrm{m}$ particle size and particle size of commercially activated carbon (CAC) in the range of 300 mesh were used as adsorbents. The Physico-Chemical properties of Ulva fasciata activated carbons and Commercially activated carbon are shown in Table-1

\section{Preparation of metal ion solution}

Stock solution of copper concentration $1000 \mathrm{mg} / \mathrm{L}$ was prepared by dissolving $3.93 \mathrm{~g}$ of $100 \% \mathrm{CuSO} 4.5 \mathrm{H} 2 \mathrm{O}$

Table 1. Physico-Chemical properties of Ulva fasciata activated carbon adsorbents and commercially activated carbon adsorben

\begin{tabular}{|l|c|c|c|c|}
\hline Properties & (CCUC) & (SSUC) & (SCUC) & (CAC) \\
\hline $\mathrm{pH}$ & 8.51 & 9.37 & 11.13 & 7.59 \\
\hline Moisture Content \% & 17.20 & 3.73 & 4.92 & 4.50 \\
\hline Ash Content \% & 12.71 & 22.40 & 17.35 & 06.77 \\
\hline Volatile Matter \% & 27.14 & 18.20 & 17.40 & 14.80 \\
\hline Fixed Carbon \% & 60.15 & 59.60 & 65.25 & 78.43 \\
\hline $\begin{array}{l}\text { Matter Soluble in } \\
\text { Water, \% }\end{array}$ & 2.03 & 0.98 & 1.28 & 3.06 \\
\hline $\begin{array}{l}\text { Matter Soluble in } \\
\text { Acid, \% }\end{array}$ & 4.50 & 1.65 & 3.70 & 5.43 \\
\hline $\begin{array}{l}\text { Surface Area } \\
\left(\mathrm{m}^{2} / \mathrm{g}\right)\end{array}$ & 17.11 & 58.23 & 41.52 & 543.45 \\
\hline $\begin{array}{l}\text { Pore } \\
\text { Volume }\left(\mathrm{cm}^{3} / \mathrm{g}\right)\end{array}$ & 0.15 & 0.38 & 0.22 & 0.51 \\
\hline Pore Size $\left(\mathrm{A}^{0}\right)$ & 304.7 & 558.4 & 398.5 & 96.08 \\
\hline
\end{tabular}

(Merck) in $1000 \mathrm{ml}$ of DD water. The solution was prepared using standard flasks. The range of concentration of the prepared metal solutions varied between 10 to $80 \mathrm{mg} / \mathrm{L}$ and they were prepared by diluting the copper stock solutions, which were obtained by dissolving in deionized water.

\section{Batch Adsorption Studies}

Batch adsorption equilibrium experiments were conducted for the adsorption of copper on activated carbons of green algae Ulva fasciata and commercially activated carbon as a function of initial $\mathrm{pH}$, initial copper concentration, adsorbent dose and contact time by adding $0.2 \mathrm{~g}$ of dried carbon to $100 \mathrm{~mL}$ of copper solution with different concentrations in $250 \mathrm{~mL}$ stoppered reagent bottles at a constant shaking speed (250 $\mathrm{rpm})$. All the experiments were carried out at room temperature $\left(28 \pm 2^{\circ} \mathrm{C}\right)$. For studying the influence of $\mathrm{pH}$ on the adsorption of $\mathrm{Cu}$ (II), the experiments were conducted at various initial metal solution $\mathrm{pH}$ values of $1-10$. The $\mathrm{pH}$ of each solution was adjusted to different values with either $\mathrm{NaOH}$ or $\mathrm{HCl}$. The concentrations of copper metal ions in solution before and after adsorption were determined using atomic adsorption spectrophotometer by monitoring the absorbance for the metal ion used. All adsorption experiments were carried out in triplicates to check the reproducibility of the results. The equilibrium and kinetics data were obtained from batch experiments.

During the adsorption, a rapid equilibrium was established between the adsorbed metal ions on the active cites of adsorbent $\left(\mathrm{q}_{\mathrm{e}}\right)$ and unadsorbed metal ion in the solution. The amount of adsorption at equilibrium $\left(\mathrm{q}_{\mathrm{e}}\right)(\mathrm{mg} / \mathrm{g})$ and the percentage adsorption $(\%)$ were computed as follows:

$q_{e}=\frac{\left(C_{0}-C_{e}\right) V}{X}$

Percentage adsorption $(\%)=\frac{\left(C_{0}-C_{e}\right)}{C_{0}} \times 100$

Where $C_{0}$ and $C_{\mathrm{e}}$ are represented the initial and equilibrium concentrations $(\mathrm{mg} / \mathrm{l}), \mathrm{V}$ is the volume of solution and $\mathrm{X}$ the weight of adsorbent $(\mathrm{g})$.

\section{RESULTS AND DISCUSSION}

\section{Effect of pH}

The $\mathrm{pH}$ of the aqueous solution is an important controlling parameter in the heavy metal adsorption process ${ }^{19}$. Therefore, the effect of hydrogen ion concentration was examined from solutions at different $\mathrm{pH}$ levels covering a range of $1.0-10.0$ with $100 \mathrm{~mL}$ of $\mathrm{Cu}$ (II) concentration $20 \mathrm{mg} / \mathrm{L}$ containing $0.2 \mathrm{~g}$ activated carbon. Fig. 1, shows that adsorption of $\mathrm{Cu}(\mathrm{II})$ increased at a steady rate as $\mathrm{pH}$ increased up to about 5, attaining a maximum value of around $85.81 \%, 95.78 \%$ and $93.16 \%$, for activated carbons prepared from Ulva fasciata CCUC, SSUC, and SCUC respectively. The minimum adsorption observed at low pH may be due to the fact that the higher concentration and higher mobility of $\mathrm{H}^{+}$ions present favoured the preferential adsorption of hydrogen ions compared to $\mathrm{Cu}$ (II) ions ${ }^{20}$. But the $\mathrm{pH}$ values from 6 to 10 lower adsorption percentage were observed for copper in activated carbons made from Ulva fasciata 


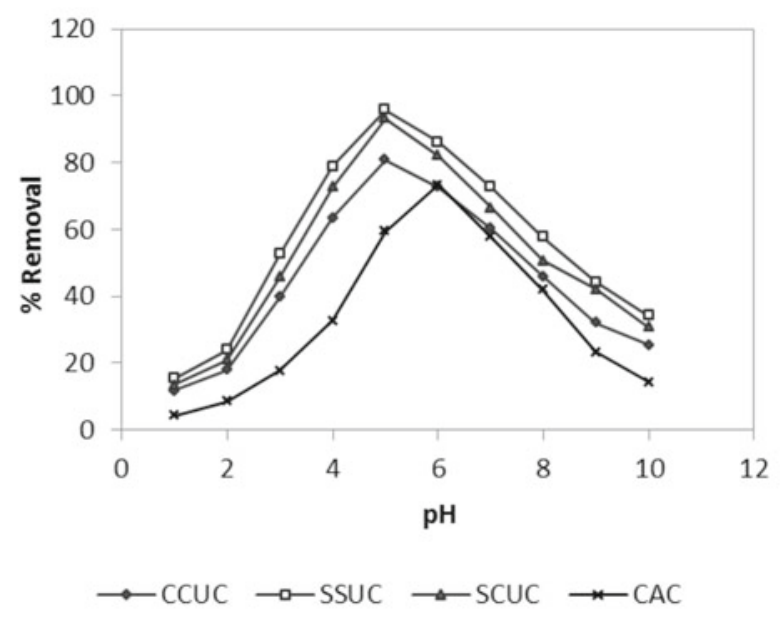

Figure 1. Effect of $\mathrm{pH}$ on the $\mathrm{Cu}$ (II) removal (initial $\mathrm{Cu}$ (II) concentration- $20 \mathrm{mg} / \mathrm{L}$, adsorbent dose $-0.2 \mathrm{~g} / 100 \mathrm{~mL}$, contact time-2h)

(CCUC, SSUC, and SCUC), this could be due to the precipitation and lower polarity of copper (II) ions at higher $\mathrm{pH}$ values. At low $\mathrm{pH}$ values, the surface of the adsorbent would be surrounded by hydronium ions, which decreases the copper ion interaction with binding sites of CCUC, SSUC, and SCUC by greater repulsive forces. As the $\mathrm{pH}$ increased the overall surface on the Ulva fasciata activated carbons became negative and adsorption increased. In this study, copper (II) ions around $\mathrm{pH} 5$ might be interacted more strongly with the negatively charged binding sites in Ulva fasciata activated carbons (CCUC, SSUC, and SCUC). It could be also observed from Fig.1, in the case of commercially activated carbon (CAC), the removal efficiency increased steadily with $\mathrm{pH}$ range up to 6 and attaining maximum value of $70.31 \%$, after $\mathrm{pH} 6$ adsorption was decreased. After $\mathrm{pH}>6.0$, $\mathrm{Cu}^{2+}$ ions were precipitated, due to hydroxide anions forming a $\mathrm{Cu}(\mathrm{OH})_{2}{ }^{19}$.

\section{Effect of contact time}

The effect of the contact time on the adsorption efficiency of $\mathrm{Cu}$ (II) on activated carbons of Ulva fasciata and CAC is shown in Fig. 2. The experiments were carried out using $100 \mathrm{~mL}$ of $\mathrm{Cu}$ (II) concentration $20 \mathrm{mg} / \mathrm{L}$ containing

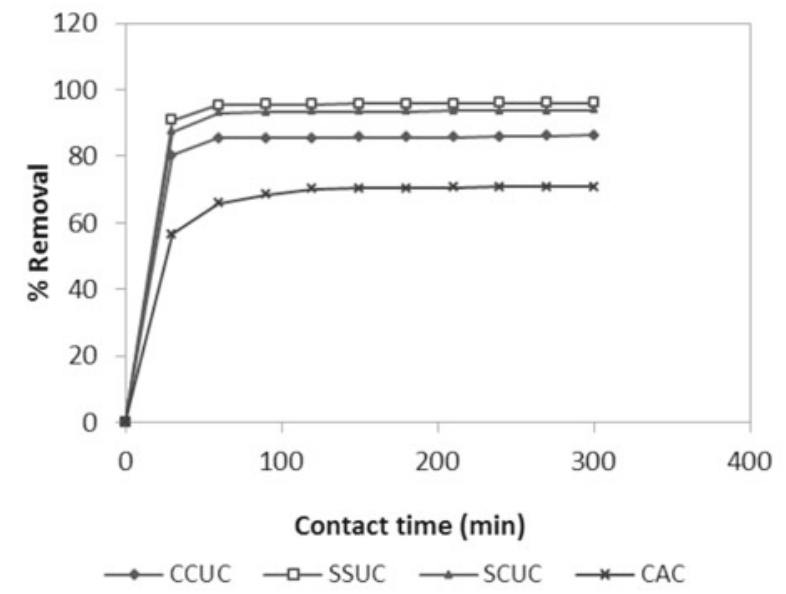

Figure 2. Effect of contact time on the $\mathrm{Cu}$ (II) removal (pH-5 for CCUC, SSUC, SCUC and 6-for CAC, initial $\mathrm{Cu}$ (II) concentration- $20 \mathrm{mg} / \mathrm{L}$, adsorbent dose- $0.2 \mathrm{~g} / 100$ $\mathrm{mL}$ )
$0.2 \mathrm{~g}$ activated carbon at $\mathrm{pH} 5$ for activated carbons of Ulva fasciata (CCUC, SCUC and SSUC) and $\mathrm{pH} 6$ for CAC. A set of solutions containing these carbons were equilibrated for varying periods ranging from 30 to 300 minutes at an agitation speed $250 \mathrm{rpm}$. From the Fig. 2, it is shown that increase in contact time increased the removal efficiency until equilibrium adsorption was established. As shown in Fig. 2 the uptake of $\mathrm{Cu}$ (II) ions increased quickly, after 30 min the change became slow. The adsorption process of $\mathrm{Cu}$ (II) on activated carbons of green algae Ulva fasciata and CAC was speedy and in $60 \mathrm{~min}$, the process of adsorption quickly reached equilibrium. After this equilibrium period, the amount of adsorbed $\mathrm{Cu}$ (II) ions not significantly changed with time. From the results, it has been observed that 1 hour time was sufficient for attaining the equilibrium for activated carbons of Ulva fasciata, the removal of $85.33 \%$ copper by CCUC, $95.40 \%$ copper by SSUC and $93.03 \%$ copper by SCUC. However $70.14 \%$ of copper was removed by $\mathrm{CAC}$ in a period of 2 hours.

\section{Effect of Cu (II) initial concentration}

The effect of the initial $\mathrm{Cu}$ (II) ion concentration on the adsorption efficiency of $\mathrm{Cu}$ (II) at activated carbons of Ulva fasciata and CAC has been shown in Fig. 3. The experiments were carried out using $100 \mathrm{~mL}$ of $\mathrm{Cu}$ (II) concentrations ranging from 10 to $80 \mathrm{mg} / \mathrm{L}$ at $\mathrm{pH} 5$ for CCUC, SSUC, SCUC and $\mathrm{pH} 6$ for CAC. An amount of $0.2 \mathrm{~g}$ of adsorbent was used for each adsorption experiment. Fig. 3 shows that the removal of $\mathrm{Cu}$ (II) was depending on the initial concentration of metal ions which decrease with the increase of initial metal ions concentration. Though an increase in metal uptake was observed, the decrease in percentage adsorption may be attributed to the lack of sufficient surface area to accommodate much more metal available in the solution. The percentage adsorption at higher concentration levels shows a decreasing trend whereas the equilibrium uptake of copper displays an opposite trend. At lower concentrations, all the copper ions present in the solution could interact with the binding sites and thus the percentage adsorption was higher than those at higher copper ion concentrations. At higher concentrations, a lower adsorption yield is due to the saturation

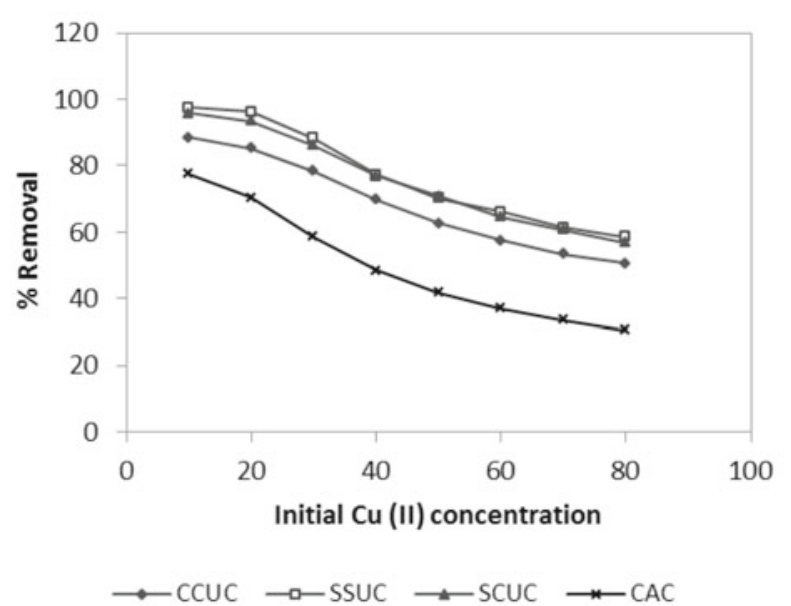

Figure 3. Effect of initial $\mathrm{Cu}$ (II) concentration on the $\mathrm{Cu}$ (II) removal (pH-5 for CCUC, SSUC, SCUC and $\mathrm{pH}-6$ for CAC, adsorbent dose $-0.2 \mathrm{~g} / 100 \mathrm{~mL}$, contact time $-2 \mathrm{~h})$ 
of adsorption sites. The maximum removal of $\mathrm{Cu}$ (II) was achieved at $10 \mathrm{mg} / \mathrm{L}$ of copper solution on CCUC, SSUC, SCUC and CAC were $88.47 \%, 97.53 \%, 95.78 \%$ and $77.42 \%$ respectively.

\section{Effect of adsorbent dose}

The dependence of copper adsorption on the amount of algae was studied by varying the adsorbent amount from $0.05 \mathrm{~g}$ to $0.4 \mathrm{~g}$ at $\mathrm{pH} 5.0$ for CCUC, SCUC, SSUC and $\mathrm{pH} 6.0$ for CAC. The experiments were carried out using $100 \mathrm{~mL}$ of $\mathrm{Cu}$ (II) concentration $20 \mathrm{mg} / \mathrm{L}$, contact time (2h) and agitation speed (250rpm). The results are graphically shown in Fig 4. It is apparent that the percentage removal of copper increases with an increase in the dose of carbon due to the greater availability of the adsorbent. Generally it can be concluded that higher dosage of adsorbent increases the \% adsorption. This is because more surfaces and binding sites for ions are available at a higher dose of adsorbents. It is known that a minimum carbon dosage of $0.15 \mathrm{~g} / 100 \mathrm{~mL}$ was sufficient for the maximum removal of $85.23 \%$ copper

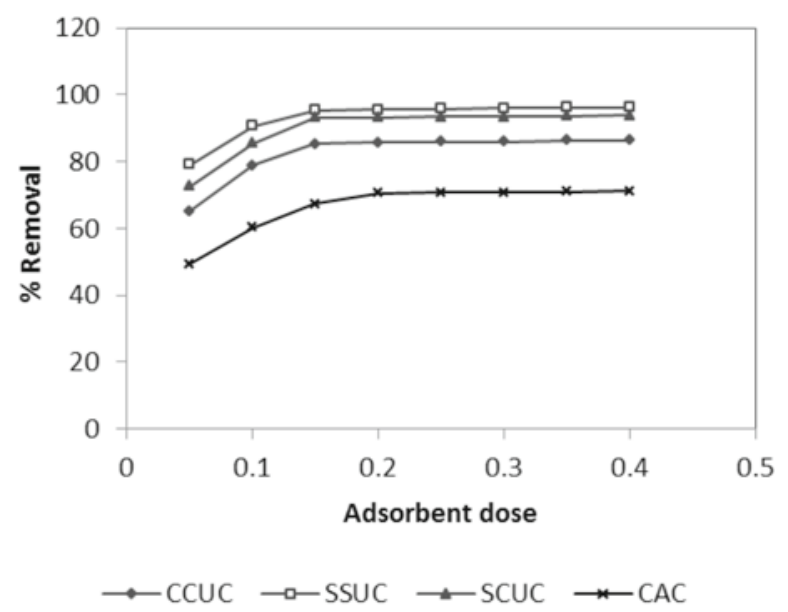

Figure 4. Effect of adsorbent dose on the $\mathrm{Cu}$ (II) removal ( $\mathrm{pH}-5$ for CCUC, SSUC, SCUC and $\mathrm{pH}-6$ for CAC, contact time- $2 \mathrm{~h}$, initial $\mathrm{Cu}$ (II) concentration- $20 \mathrm{mg} / \mathrm{L}$ )

by CCUC, $95.28 \%$ copper by SSUC and $93.13 \%$ copper by SCUC. But $0.20 \mathrm{~g} / 100 \mathrm{~mL}$ of CAC required for maximum removal of $70.59 \%$ copper. The results show that SSUC was found to be a superior adsorbent than other activated carbons.

\section{Adsorption Isotherms}

The capacity of an adsorbent can be described by equilibrium adsorption isotherm. The isotherm represents the equilibrium relationship between the metal uptake by the adsorbent and the final metal concentration in the aqueous phase. Several isotherm equations are available, three important isotherms are chosen in this study, which are namely the Langmuir, Freundlich and Temkin isotherms.

\section{Langmuir Isotherm}

The Langmuir adsorption isotherm describes the surface as homogeneous assuming that all the adsorption sites have equal adsorbate affinity and that adsorption at one site does not affect adsorption at an adjacent $\operatorname{site}^{21,22}$. The Langmuir equation may be written as

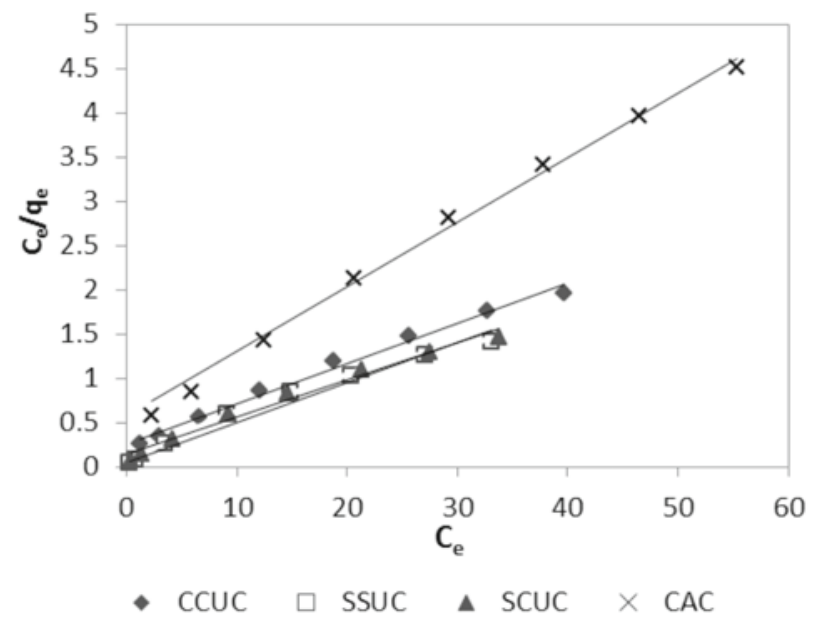

Figure 5. Langmuir isotherm for $\mathrm{Cu}$ (II) onto activated carbons (CCUC, SSUC and SCUC) from Ulva fasciata and $\mathrm{CAC}$

$q_{e}=\frac{Q_{0} b C_{e}}{1+b C_{e}} \quad$ (nonlinear form)

$\frac{C_{e}}{q_{e}}=\frac{1}{Q_{0} b}+\frac{C_{e}}{Q_{0}}$

(linear form)

Where $q_{\mathrm{e}}$ is the amount of solute adsorbed per unit weight of adsorbent $(\mathrm{mg} / \mathrm{g}), C_{\mathrm{e}}$ the equilibrium concentration of solute in the bulk solution $(\mathrm{mg} / \mathrm{L}), Q_{0}$ the monolayer adsorption capacity $(\mathrm{mg} / \mathrm{g})$ and $b$ is the constant related to the free adsorption energy.

\section{Freundlich Isotherm}

Freundlich isotherm was used to describe the adsorption pattern $^{23}$ describes the equilibrium on heterogeneous surfaces and does not assume monolayer capacity. The Freundlich equation is

$\frac{X}{m}=K_{F} C_{e}^{\frac{1}{n}} \quad$ (nonlinear form)

$\log \frac{X}{m}=\log K_{F}+\frac{1}{n} \log C_{e} \quad$ (linear form)

Where $X$ is the amount of the solute adsorbed (mg), $\mathrm{m}$ is the mass of the adsorbent $(\mathrm{g}), C$ e the equilibrium concentration of solute in the bulk solution $(\mathrm{mg} / \mathrm{L}), K_{\mathrm{F}}$ a constant indicative of the relative adsorption capacity

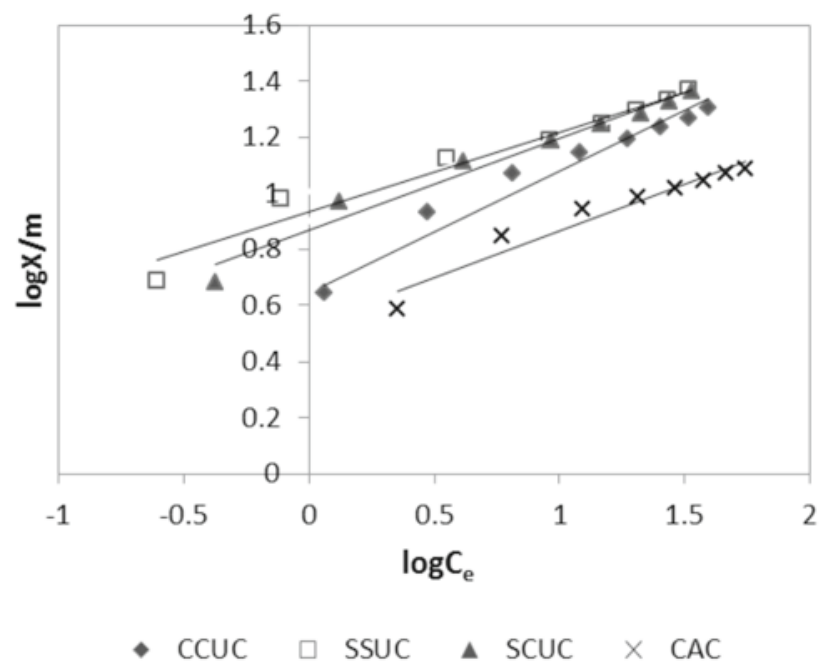

Figure 6. Freundlich isotherm of $\mathrm{Cu}$ (II) onto activated carbons (CCUC, SSUC and SCUC) from Ulva fasciata and $\mathrm{CAC}$ 
Table 2. Langmuir, Freundlich and Temkin isotherms and their constants

\begin{tabular}{|c|c|c|c|c|c|}
\hline \multirow{2}{*}{\multicolumn{2}{|c|}{ Isotherms \& constants }} & \multicolumn{4}{|c|}{ Adsorbents } \\
\hline & & CCUC & SSUC & SCUC & CAC \\
\hline \multirow{3}{*}{ Langmuir } & $\mathrm{Q}_{0}$ & 22.221 & 23.640 & 23.860 & 13.774 \\
\hline & $\mathrm{b}$ & 0.173 & 0.367 & 0.299 & 0.125 \\
\hline & $\mathrm{R}^{2}$ & 0.989 & 0.978 & 0.988 & 0.994 \\
\hline \multirow{3}{*}{ Freundlich } & $\mathrm{K}_{\mathrm{F}}$ & 1.905 & 1.328 & 2.379 & 1.704 \\
\hline & $\frac{1}{n}$ & 0.429 & 0.224 & 0.328 & 0.332 \\
\hline & $\mathrm{R}^{2}$ & 0.953 & 0.960 & 0.971 & 0.944 \\
\hline \multirow{3}{*}{ Temkin } & $\mathrm{K}_{\mathrm{T}}$ & 1.460 & 3.332 & 2.370 & 1.461 \\
\hline & $B$ & 4.250 & 3.434 & 3.922 & 2.495 \\
\hline & $\mathrm{R}^{2}$ & 0.994 & 0.964 & 0.981 & 0.991 \\
\hline
\end{tabular}

of the adsorbent $(\mathrm{mg} / \mathrm{g})$ and the constant $1 / n$ indicates the intensity of the adsorption.

\section{Temkin Isotherm}

Temkin isotherm is given as

$q_{e}=\mathrm{B} \ln \left(\mathrm{K}_{\mathrm{T}} \mathrm{C}_{\mathrm{e}}\right) \quad$ (nonlinear form)

It can be expressed in the linear form as

$q_{e}=\mathrm{B} \ln \mathrm{K}_{\mathrm{T}}+\mathrm{B} \ln \mathrm{C}_{\mathrm{e}} \quad$ (linear form)

Where $B=\frac{R T}{b}$, a plot of $q_{e}$ versus $\mathrm{h} C_{\mathrm{e}}$ enables the

determination of the Isotherm constants $\mathrm{B}$ and $\mathrm{K}_{\mathrm{T}}$ from the slope and the intercept, respectively. $\mathrm{K}_{\mathrm{T}}$ is the equilibrium binding constant corresponding to the maximum binding energy and constant $\mathrm{B}$ is related to the heat of adsorption $^{\mathbf{2 4}}$. The sorption capacity for copper the metal increased with an increase in the metal concentration in solution. The experimental data were modeled according to Langmuir, Freundlich and Temkin isotherm, and the evaluated constants are given in Table 2.

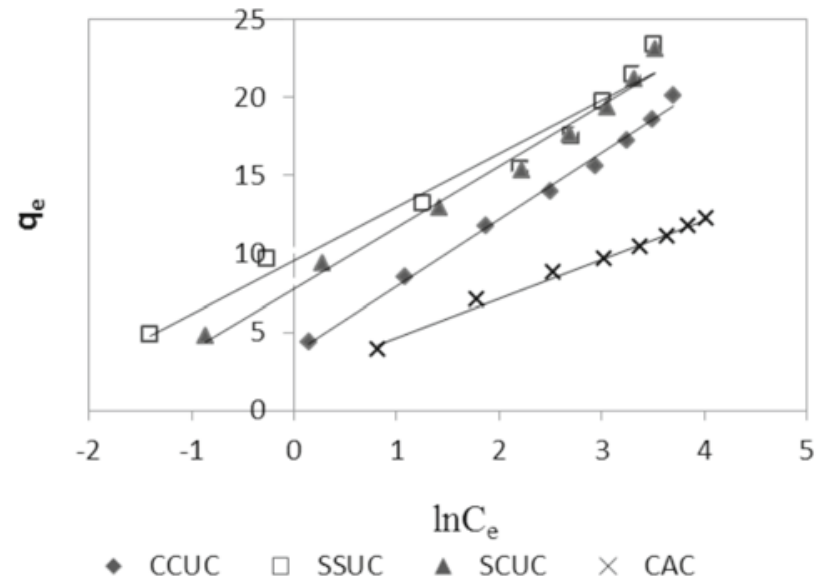

Figure 7. Temkin isotherm of $\mathrm{Cu}$ (II) onto activated carbons (CCUC, SSUC and SCUC) from Ulva fasciata and $\mathrm{CAC}$

\section{Kinetic Studies}

In order to understand the adsorption kinetics of Copper (II) ions, two kinetic models, which are pseudo first order and pseudo second order, have been applied for the experimental data.

\section{The pseudo-first order equation}

Kinetic analysis is required to get an insight of the rate of adsorption and the rate limiting step of the transport mechanism, which are primarily used in the modeling, and design of the process. The pseudo-first order equation of Lagergren ${ }^{\mathbf{2 5}}$ is generally expressed as follows:

$\frac{d q_{t}}{d t}=k_{1}\left(q_{e}-q_{t}\right)$

Where, $q_{e}$ and $q_{t}$ are the sorption capacities at equilibrium and at time $t$, respectively $(\mathrm{mg} / \mathrm{g})$ and $k_{1}$ is the rate constant of pseudo-first order sorption, $(1 / \mathrm{min})$. After integration and applying boundary conditions, $q_{t}$ $=0$ to $q_{t}=q_{t}$ at $t=0$ to $t=t$ the integrated form of equation (9) becomes:

$\log \left(q_{e}-q_{t}\right)=\log q_{e}-\frac{k_{1}}{2.303} t$

The pseudo first order rate constant $k_{1}$ can be obtained from the slope of plot between $\log (q \mathrm{e}-q \mathrm{t})$ versus time (t). Fig. 8 shows the Lagergren pseudo-first order kinetic plot for the adsorption of copper onto activated carbons of green algae Ulva fasciata and CAC. The calculated $k_{1}$ values and their corresponding linear regression correlation coefficient values are shown in Table-3.

The pseudo second order equation

A pseudo-second-order model proposed by Ho and $\mathrm{McKay}^{\mathbf{2 6}}$ was then used to explain the sorption kinetics. The pseudo-second order chemisorption kinetic rate equation is expressed as:

$\frac{d q_{t}}{d t}=k_{2}\left(q_{e}-q_{t}\right)^{2}$

Table 3. Pseudo first order and pseudo second order constants and their correlation coefficients

\begin{tabular}{|c|c|c|c|c|c|}
\hline \multirow{2}{*}{\multicolumn{2}{|c|}{ Kinetics \& constants }} & \multicolumn{4}{|c|}{ Adsorbents } \\
\hline & & CCUC & SSUC & SCUC & CAC \\
\hline \multirow{3}{*}{ Pseudo first order } & $\mathrm{K}_{1}$ & 0.0092 & 0.0142 & 0.0140 & 0.0191 \\
\hline & $q_{e}$ & 1.612 & 1.700 & 1.794 & 1.119 \\
\hline & $\mathrm{R}^{2}$ & 0.731 & 0.843 & 0.832 & 0.963 \\
\hline \multirow{3}{*}{ Pseudo second order } & $\mathrm{K}_{2}$ & 0.0658 & 0.0382 & 0.0772 & 0.0232 \\
\hline & $q_{e}$ & 8.665 & 9.775 & 9.416 & 7.246 \\
\hline & $\mathrm{R}^{2}$ & 1.000 & 0.999 & 1.000 & 0.999 \\
\hline
\end{tabular}




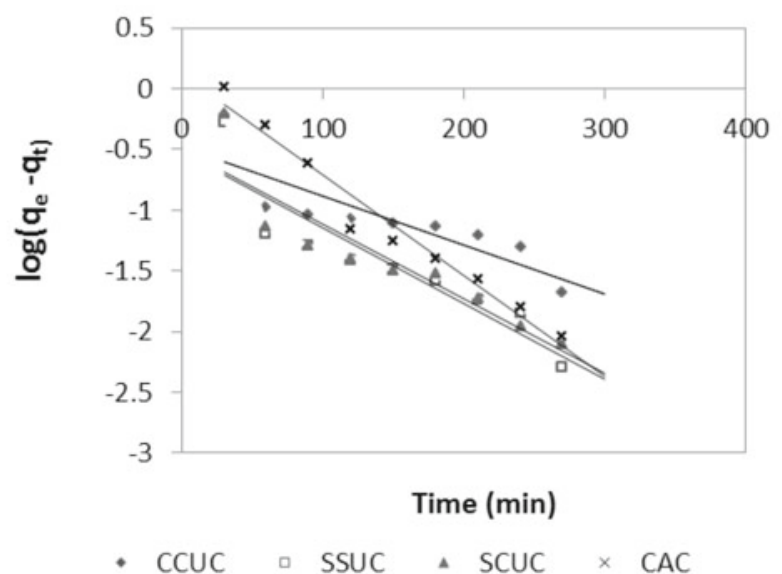

Figure 8. Pseudo first order kinetics of $\mathrm{Cu}$ (II) onto activated carbons (CCUC, SSUC, SCUC) from Ulva fasciata and $\mathrm{CAC}$

Where $q_{e}$ and $q_{t}$ are the sorption capacity at equilibrium and at time $t$,respectively $(\mathrm{mg} / \mathrm{g})$ and $k_{2}$ is the rate constant of pseudo-second order sorption, $(\mathrm{g} / \mathrm{mg} \mathrm{min})$ for the boundary conditions $q_{t}=0$ to $q_{t}=q_{t}$ at $t=0$ to $t=t$; the integrated form of equation (11) becomes: $\frac{t}{q_{t}}=\frac{1}{k_{2} q_{e}^{2}}+\frac{1}{q_{e}} t$

Where $t$, is the contact time $(\mathrm{min}), q_{e}(\mathrm{mg} / \mathrm{g})$ and $q_{t}$ $(\mathrm{mg} / \mathrm{g})$ are the amount of the solute adsorbed at equilibrium and at any time, t. If the pseudo-second order kinetics is applicable, the plot of $\mathrm{t} / q_{t}$ against $t$ of equation (12) should give a linear relationship, from which $q_{t}$ and $k_{2}$ can be determined from the slope and intercept of the plot (Figure-9).

The pseudo-second order rate constant $k_{2}$, the calculated $q_{e}$ value and the corresponding linear regression correlation coefficient value $\mathrm{R}^{2}$ are given in Table.3. At all initial copper concentrations, the linear regression correlation coefficient $\mathrm{R}^{2}$ values confirm that the adsorption data are well represented by the pseudo-second order kinetics and supports the assumption behind the model that the adsorption is due to chemisorptions.

Kinetics only deals with the motion of the solute and dynamics deals with the reason why they move, this is the main difference between kinetics and dynamics study. An adsorption kinetics describes the solute adsorption rate, which also provides valuable information about the mechanism of adsorption and subsequently investigation of the controlling mechanism of the adsorption process. While dynamics focuses on the force and their effects, an adsorption isotherm is a graphical representation showing the relationship between the amounts adsorbed by a unit weight of adsorbent and the amount of adsorbate remaining in a test medium at equilibrium.

While comparing the percentage removal and adsorption capacity of activated carbons made from Ulva fasciata (CCUC, SCUC and SSUC) with commercially activated carbon (CAC), the activated carbons of Ulva fasciata are superior adsorbents than the commercially activated carbon. This is due to the negatively charged binding sites in Ulva fasciata activated carbons, which are found more than that of the activated carbon.This could be seen from table- 4 .

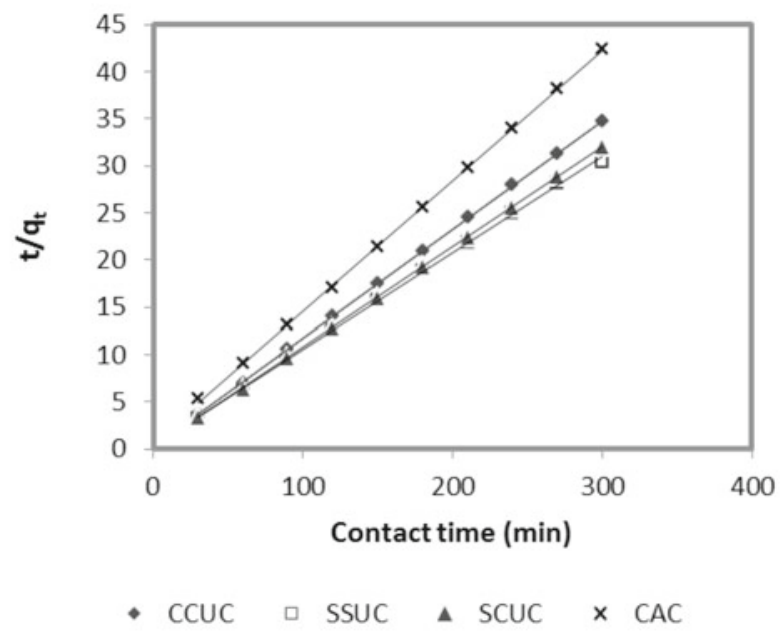

Figure 9. Pseudo second order kinetics of $\mathrm{Cu}$ (II) onto activated (CCUC, SSUC and SCUC) carbons from Ulva fasciata and CAC

Table 4. Comparison between activated carbon made from Ulva fasciata with the commercially activated carbon on adsorption of copper (II) ions

\begin{tabular}{|l|c|c|c|c|}
\hline Parameters & CCUC & SSUC & SCUC & CAC \\
\hline $\begin{array}{l}\text { Maximum \% } \\
\text { removal }\end{array}$ & 88.47 & 97.53 & 95.78 & 77.42 \\
\hline Optimum pH & 5 & 5 & 5 & 6 \\
\hline Optimum time & $1 \mathrm{~h}$ & $1 \mathrm{~h}$ & $1 \mathrm{~h}$ & $2 \mathrm{~h}$ \\
\hline $\begin{array}{l}\text { Adsorbent } \\
\text { dose }\end{array}$ & $0.15 \mathrm{~g}$ & $0.15 \mathrm{~g}$ & $0.15 \mathrm{~g}$ & $0.2 \mathrm{~g}$ \\
\hline $\begin{array}{l}\text { Adsorption } \\
\text { capacity }\end{array}$ & 22.22 & 23.64 & 23.86 & 13.77 \\
\hline
\end{tabular}

\section{CONCLUSIONS}

In the present study, the activated carbons (CCUC, SSUC and SCUC) prepared from marine green algae Ulva fasciata and commercially activated carbon (CAC) were used as adsorbents for removing $\mathrm{Cu}(\mathrm{II})$ ions from aqueous solution. The batch study parameters, $\mathrm{pH}$ of solution, contact time, initial $\mathrm{Cu}$ (II) concentration and adsorbent dose were found to be effective on the adsorption efficiency of $\mathrm{Cu}(\mathrm{II})$. The kinetic studies revealed that the adsorption of copper shows that the pseudo-second order model provides better correlation of adsorption data than the pseudo-first-order model. The Langmuir and Temkin isotherm models were fitted well than Freundlich isotherm.

\section{LITERATURE CITED}

1. Dahiya, S., Tripathi, R.M. \& Hegde, A.G., (2008). Biosorption of heavy metals and radionuclide from aqueous solutions by pre- treated arca shell biomass, J. Hazard Mater. 150, 376-386. DOI:10.1016/j.hazmat 2007.04.134.

2. Sprynskyy, M., Buszewski, B. \& Terzyk, A.P., Namie'snik, J., (2006). Study of the selection mechanism of heavy Metal $\mathrm{Pb}^{2+}, \mathrm{Cu}^{2+}, \mathrm{Ni} 2+$ and $\left.\mathrm{Cd} 2+\right)$ adsorption on clinoptilolite, J. Colloid Interf. Sci. 304, 21-28. DOI:10.1016/j.jcis 2006.07.068.

3. Davis, T.A., Volesky, B. \& Vieira, R.H.S.F., (2000). Sargassum seaweed as biosorbent for heavy metals. Water Res. 34, 4270-4278.

4. Primary Drinking Water Rules., (1992). Sec.141.32 (e) (20), Federal Regulations, The Bureau of National Affairs, Inc.,

5. Kuyucak, N. \& Volesky, B., (1998). Biosorbent for recovery of metals from industrial solutions. Biotechnol Lett 10:137-142.

6. Pagnanelli, F., Pietrangeli, M., Toro, L., Trifoni, M. \& Veglio, F., (2003). Biosorption of metal ions on Arthrobacter sp.: biomass characterization and bisortpion modelling, Environ. Sci. Technol. 34, 2773-2778. 
Table 5. Comparison between the adsorption of $\mathrm{Cu}$ (II) for present study and other adsorbents found in the literature

\begin{tabular}{|c|c|c|c|c|c|}
\hline \multirow[b]{2}{*}{ Adsorbent } & \multicolumn{3}{|c|}{ Operation conditions } & \multirow[b]{2}{*}{$\begin{array}{c}q \max \\
(\mathrm{mg} / \mathrm{g})\end{array}$} & \multirow[b]{2}{*}{ Ref } \\
\hline & $\mathrm{pH}$ & $\begin{array}{c}C_{0} \\
(\mathrm{mg} / \mathrm{L})\end{array}$ & $\begin{array}{c}X \\
(g / L)\end{array}$ & & \\
\hline Chlorella vulgaris & 4.5 & 100 & 1 & 40 & [27] \\
\hline Scenedesmus obliquus & 4.5 & 100 & 1 & 20 & [27] \\
\hline Synechocystis sp. & 4.5 & 100 & 1 & 23.4 & [27] \\
\hline Chlorella fusca & 6 & 6.3 & n.a & 3.2 & [28] \\
\hline Chlorella vulgaris & 5 & 5 & 1 & 1.8 & [29] \\
\hline Scenedosmus quadricauda & 4 & 5 & 1 & 2.8 & [29] \\
\hline Saccharomyces cerevisiae & 5 & 100 & 0.1 & 1.25 & [30] \\
\hline O. Limnetica & $4-5$ & 1000 & 1 & 23.96 & [31] \\
\hline A. Spiroides & $4-5$ & 1000 & 1 & 0.2 & [31] \\
\hline E. Elegans & $4-5$ & 1000 & 1 & 1.08 & [31] \\
\hline C. Vulgaris & 4.5 & 1000 & 1 & 9.47 & [31] \\
\hline Manihot esculenta Cranz & 5 & 500 & 2.5 & 71.3 & [32] \\
\hline Thuja orientalis & 7.7 & 50 & 4 & 19.23 & [33] \\
\hline $\begin{array}{l}\text { Ecklonia radiate } \\
\text { ( } \mathrm{CaCl}_{2} \text {-pretreated) }\end{array}$ & 5 & n.a & 2 & 1.11 & [34] \\
\hline $\begin{array}{l}\text { Durvillaea potatorum } \\
\text { ( } \mathrm{CaCl}_{2} \text {-pretreated) }\end{array}$ & 5 & n.a & 2 & 1.30 & [34] \\
\hline Ulva facsiata activated carbon $\left(\mathrm{CaCl}_{2}\right.$-pretreated) & 5 & 100 & 0.2 & 22.22 & This study \\
\hline $\begin{array}{l}\text { Ulva facsiata activated carbon } \\
\text { (NaSO } \text {-pretreated) }^{- \text {ated }}\end{array}$ & 5 & 100 & 0.2 & 22.17 & This study \\
\hline $\begin{array}{l}\text { Ulva facsiata activated carbon } \\
\left(\mathrm{NaCO}_{3} \text {-pretreated) }\right.\end{array}$ & 5 & 100 & 0.2 & 23.17 & This study \\
\hline Commercially activated carbon & 6 & 100 & 0.2 & 13.77 & This study \\
\hline
\end{tabular}

n.a : not available

7. Pagnanelli, F., Trifoni, M., Bcolchini, R., Esposito, A., Toro, L. \& Veglio, F., (2001). Equilibrium biosorption studies in single and multi-metal systems, Process Biochem. 37 (2), 115-124.

8. Volesky, B., (1987). Biosorbents for metal recovery,Trends Biotechnol. 5, 96-101.

9. Gadd, G.M. \& White, C., (1993). Microbial treatment of metal pollution: a Working biotechnology, Trends Biotechnol 11, 353-360.

10. Ramelow, G.J., Fralick, D. \& Zhao, Y., (1992). Factors affecting the uptake of aqueous metal ions by dried seaweed biomass, Microbios 72, 81-93.

11. Vilar, V.J.P., Botelho, C.M.S. \& Boaventura, R.A.R., (2008). Lead and copper biosorption by marine red algae Gelidium and algal composite material in a CSTR ("Carberry" type), Chem. Eng. J. 138, 249-257.

12. Vilar, V.J.P., Botelho, C.M.S., Boaventura, R.A.R., (2008). Metal biosorption by algae Gelidium derived materials from binary solutions in a continuous stirred adsorber, Chem. Eng. J. 141, 42-50.

13. Babel, S., Kurmiawan, T.A., (2003). Low-cost adsorbents for heavy metals uptake from contaminated water: a review, J. Hazard. Mater. B 97, 219- 243.

14. El-Sikaily, A., Khaled A., El Nemr, A. \& Abdelwahab, O., (2006). Removal of methylene blue from aqueous solution by marine green alga Ulva lactuca, Chem. Ecol. 22 149-157.

15. Abdelwahab, O., El Nemr, A., El-Sikaily, A., Khaled, A., (2006). Biosorption of Direct Yellow 12 from aqueous solution by marine green algae Ulva Lactuca, Chem. Ecol. 22, 253- 266.

16. Abdelwehab, O., El Sikaily, A., El Nemr, A., Khaled, A., (27-29th May 2006). Biosorption of copper from aqueous solution by biomass of marine Ulva lettuce and its activated carbon, in: International Conference on Marine Pollution in the Arab Region, Sheraton El Montaza, Alexandria, Egypt, p.13.

17. Gong, R., Ding, Y.D., Liu, H., Chen, Q. \& Liu, Z., (2005). Lead biosorption by intact and pretreated spirulina maxima biomass, Chemosphere 58, 125-130.

18. Karthikeyan, S., Sivakumar, P. \& Palanisamy, P.N., (2008). Novel Activated Carbons from Agricultural Wastes and their Characterization, E-Journal of chemistry 5, 409-426.

19. Aydın, H., Bulut, Y., Yerlikaya, C., (2008). Removal of copper (II) from aqueous solution by adsorption onto low-cost adsorbents, Journal of Environmental Management 87, 37-45.

20. Ajmal, Rao, M., Ahmad, R. A. K., and Ahmad, R., (2000). Adsorption studies on Citrus reticulate (fruit peel of orange): removal and recovery of $\mathrm{Ni}$ (II) from electroplating wastewater. Hazardous Materials, 79, 117-131.

21. Langmuir I., (1918). The adsorption of gases on plane surfaces of glass, mica and platinum, J. Am. Chem. Soc. 40, 1361-1367.

22. Weber, Jr. W.J., (1972). Physicochemical Processes for Water Quality Control, Wiley/Inter-science, New York.

23. Freundlich, H. \& Helle,W.J., (1939). Ruber die adsorption in Lusungen Journal of American Chemical Society, 61, 2-28.

24. Seker A., Shahwan T., Eroglu A.E., Yilmaz S., Demirel Z. \& Dalay M.T., (2008). Equilibrium thermodynamic and kinetic studies for the biosorption of aqueous lead(II), cadmium(II) and nickel(II) ions on Spirulina platensis, J. Hazard. Mater. 154, 973-980. DOI:10.1016/j.hazmat 2007.11.007.

25. Lagergren, S. \& Kungliga, S., (1898). Svenska Ventenskapsakademiens. Handlingar, Band. 24(4):1.

26. Ho, Y.S. \& McKay, G., (1999). The sorption of lead (II) ions on peat. Water Research 33, 578-584.

27. Cetinkaya Donmez, G., Aksu, Z., Ozturk, A., Kutsa, T., (1999). A comparative study on heavy metal biosorption characteristics of some algae, Process Biochem. 34, 885-892.

28. Aksu, Z., Wong, Y.S. \& Tam, N.F.Y., (1998). Algae for Waste Water Treatment, Springer-Verlag/Landes Bioscience, Germany, pp. 37-53 (Chapter3).

29. Harris, P.O. \& Ramelow, G.J., (1990). Binding of metal ions by particulate biomass derived from Chlorella vulgaris: Part I individual ion species, Environ.Sci. Technol. 24, 220-228.

30. Jianlong, W., (2002). Biosorption of copper(II) by chemically modified biomass of Saccharomyces cerevisiae, Process Biochem. 37, 847-850.

31. Tien, C.J., (2002). Biosorption of metal ions by freshwater algae with different surface characteristics, Process Biochem. 38, 605-613.

32. Horsfall Jr, M., Abia, A.A. \& Spiff, A.I., (2003). Sorption of cadmium(II) and zinc(II) ions from aqueous solutions by cassava waste biomass (Manihot sculenta Cranz), Afr. J. Biotechnol. 2 (10), 360-364.

33. Nuhoglu, Y. \& Oguz, E., (2003). Removal of copper(II) from aqueous solutions by biosorption on the cone biomass of Thuja orientalis, Process Biochem.38, 1627-1631.

[34] Matheickal, J.T., Yu. Q., (1999). Biosorption of lead (II) and copper(II) from aqueous solutions by pre-treated biomass of Australian marine algae. Bioresource Technol. 69, 223-229. 